\title{
Activity of cyazofamid against Sclerospora graminicola, a downy mildew disease of pearl millet
}

\author{
Sudisha Jogaiah, ${ }^{1}$ Shigeru Mitani, ${ }^{2}$ Amruthesh Kestur Nagaraj ${ }^{1}$ and \\ Shetty Huntrike Shekar ${ }^{1 *}$ \\ ${ }^{1}$ Downy Mildew Research Laboratory, Department of Studies in Applied Botany, Seed Pathology and Biotechnology, University of Mysore, \\ Manasagangotri, Mysore 570 006, India \\ ${ }^{2}$ Central Research Institute, Ishihara Sangyo Kaisha Ltd, 2-3-1 Nishi-Shibukawa, Kusatsu, Shiga 525-0025, Japan
}

\begin{abstract}
The efficacy of cyazofamid was tested against pearl millet downy mildew disease caused by Sclerospora graminicola Schroet. Significant inhibition of sporangial sporulation, zoospore release and motility was observed at $0.3 \mathrm{mg} \mathrm{mL} \mathrm{mL}^{-1}$, and this concentration also provided good fungicidal activity under in vitro conditions. Under glasshouse conditions, none of the concentrations tested, either $0.01-2 \mathrm{mg} \mathrm{mL}^{-1}$ as seed treatment or 1-10 mg $\mathrm{mL}^{-1}$ by foliar application, was found to be phytotoxic. The effect of cyazofamid was tested by seed treatment alone, seed treatment followed by foliar application and foliar application alone. Seed treatment with cyazofamid offered only $19.7 \%$ disease control, but seed treatment followed by a single foliar application to diseased plants provided good control over disease, seed treatment with two foliar applications was significantly superior and foliar application alone showed a high level of activity, with $10 \mathrm{mg} \mathrm{mL}^{-1}$ giving $97.9 \%$ disease control. Lack of systemic activity of cyazofamid was evident, root treatment giving disease levels on a par with the untreated control. The fungicide exhibited strong curative activity, but only moderate translaminar activity, with only marginal (34.8\%) disease control after treatment of the adaxial leaf surface at $10 \mathrm{mg} \mathrm{mL}^{-1}$. Loss of cyazofamid activity over time was very low, indicating stable residual and rainfastness activity. These results indicate that cyazofamid has a high potential to be an effective fungicide for the control of downy mildew disease of pearl millet.

(C) 2007 Society of Chemical Industry
\end{abstract}

Keywords: pearl millet; Pennisetum glaucum; downy mildew; Sclerospora graminicola; cyazofamid; disease management

\section{INTRODUCTION}

Pearl millet [Pennisetum glaucum (L.) R. Br.] is the only cereal that reliably provides grain and fodder under dry land conditions. It is grown in India in an area of 11.2 million ha and is the staple food for millions of poor people in arid and semi-arid regions of the country. Pearl millet is rich in nutrition compared with other cereals and adapts well to low-fertility soils in areas receiving less than $400 \mathrm{~mm}$ of annual precipitation. ${ }^{1}$ However, downy mildew caused by Sclerospora graminicola (Sacc.) Schroet is a major biotic constraint, causing an annual economic loss of \$US 270 million, and is an important biological constraint in the major pearl millet growing countries. ${ }^{2}$ It is highly destructive and widespread. ${ }^{3}$ An estimated yield loss of up to $80 \%$ has been recorded in F1 hybrids, and many epidemics have been recorded. The oomycetes have distinct physiology, which causes many of the most effective fungicides to fail against them. ${ }^{4}$ The systemic phenylamide fungicide metalaxyl has been used successfully since the 1970 s to control this disease and significantly increases the yield. ${ }^{3-6}$ Evolution of metalaxyl-resistant strains among Oomycetes of plant pathogens has led to the exploration of new chemicals for downy mildew management.

Cyazofamid, 4-chloro-2-cyano- $N, N$-dimethyl-5$p$-tolylimidazole-1-sulfonamide, a fungicide of the phenylimidazole chemical class, was discovered and is being developed by Ishihara Sangyo Kaisha, Ltd. Cyazofamid exhibits a broad spectrum of activity against Oomycetes and Plasmodiophoromycetes at very low rates. ${ }^{7}$ It has a good toxicological, ecotoxicological and environmental profile. The mode of action of cyazofamid is blocking electron transfer in the mitochondrial cytochrome $b c_{1}$ complex by binding the $\mathrm{Q}_{\mathrm{i}}$ centre of the enzyme. Since this mode of action differs from those of other currently registered and commonly used fungicides, there is no cross-resistance between cyazofamid and other fungicides, including the strobilurin-type fungicides and the phenylamides. ${ }^{8}$

There are some reports that cyazofamid is best used as a foliar application for potato, grapevine,

* Correspondence to: Shetty Huntrike Shekar, Downy Mildew Research Laboratory, Department of Studies in Applied Botany, Seed Pathology and Biotechnology, University of Mysore, Manasagangotri, Mysore 570 006, Karnataka, India

E-mail: hss_uom@hotmail.com

Contract/grant sponsor: Indian Council of Agricultural Research (ICAR), Government of India, through the All-India Coordinated Pearl Millet Improvement Programme (AICPMIP)

(Received 10 March 2006; revised version received 18 December 2006; accepted 19 December 2006)

Published online 14 May 2007; DOI: 10.1002/ps.1383 
tomato, cucurbits, onion, lettuce, rice and Chinese cabbage, ${ }^{7-13}$ but there are no data concerning the effect of cyazofamid against pearl millet downy mildew.

This paper describes the sensitivity of $S$. graminicola, a downy mildew pathogen of pearl millet, to cyazofamid, the effect of the latter on downy mildew disease under greenhouse conditions and the chemical nature of the fungicide.

\section{MATERIALS AND METHODS 2.1 Fungicide}

Cyazofamid was used as a $100 \mathrm{gL}^{-1}$ SC $\left(\operatorname{Ranman}^{\circledR}\right.$; Ishihara Sangyo Kaisha Ltd) throughout this study.

\subsection{Plants}

Pearl millet cultivar 7042S, which is highly susceptible to $S$. graminicola, was used for all tests. Seeds were sown into soil in the field or previously divided into earthen pots $(12-15 \mathrm{~cm}$ diameter $)$.

\subsection{In vitro studies}

\subsubsection{Preparation of inoculum}

Zoosporangia of $S$. graminicola collected from highly diseased leaves of 21-day-old plants of 7042S cultivar in the field were used for inoculation. In the evening, existing zoosporangia were brushed and removed from the diseased leaves into tap water. After surface wetness had been removed, leaves were incubated in a moist chamber overnight. In the early morning, zoosporangia were harvested and the spore load was adjusted to $4 \times 10^{4}$ cells $\mathrm{mL}^{-1}$ using a haemocytometer.

\subsubsection{Sensitivity of Sclerospora graminicola to cyazofamid fungicide}

2.3.2.1 Inhibition of sporulation. Symptomatic leaf tissue was collected from infected plants and existing zoosporangia were brushed and removed from the diseased leaves into tap water. After leaf surface wetness had been removed, leaves were cut into $1 \mathrm{~cm}^{2}$ pieces and subsequently treated (smeared) with aqueous dispersions of $0.01,0.05,0.1,0.15,0.2$, 0.25 or $0.3 \mathrm{mg} \mathrm{mL}^{-1}$ cyazofamid for $30 \mathrm{~min}$. Sterile distilled water treatment to infected leaves $\left(1 \mathrm{~cm}^{2}\right)$ served as control. Treated leaves were then incubated in moist chambers in the dark for $12 \mathrm{~h}$ and examined for sporulation. Sporangia from each treatment were harvested in $1 \mathrm{~mL}$ sterile distilled water, and spore load (inhibition) was assessed using a haemocytometer.

2.3.2.2 Inhibition of zoospore release and zoospore motility. Sporangial suspensions of $S$. graminicola $\left(5 \times 10^{4}\right.$ zoosporangia $\left.\mathrm{mL}^{-1}\right)$ were treated with 0.01 , $0.05,0.1,0.15,0.2,0.25$ or $0.3 \mathrm{mg} \mathrm{mL}^{-1}$ cyazofamid in $1: 1(\mathrm{v} / \mathrm{v})$ ratio for 15 and $30 \mathrm{~min}$ under dark conditions. Zoospore release was assessed by counting the empty and intact sporangia microscopically.
A zoospore suspension of $S$. graminicola $\left(5 \times 10^{4}\right.$ zoospores $\mathrm{mL}^{-1}$ ) was treated with cyazofamid in $1: 1(\mathrm{v} / \mathrm{v})$ ratio for $15-30 \mathrm{~min}$, and zoospore motility was observed under a microscope (five different fields). The relative percentage zoospore motility was calculated on the basis of the numbers of zoospores showing motility in treated suspensions compared with that in the control.

2.3.2.3 Fungistatic and fungicidal properties of cyazofamid. Cyazofamid at 0.01, 0.05, 0.1, 0.15, 0.2, 0.25 and $0.3 \mathrm{mg} \mathrm{mL}^{-1}$ was added to zoosporangia suspensions of $S$. graminicola $\left(5 \times 10^{4}\right.$ zoosporangia $\left.\mathrm{mL}^{-1}\right)$ and incubated for $15-30 \mathrm{~min}$. The sporangial suspension was then separated and removed from the cyazofamid by centrifugation $(3000 \mathrm{rpm}$ for $5 \mathrm{~min}$ at $4{ }^{\circ} \mathrm{C}$ ). Pellets of zoosporangia were washed with distilled water twice with centrifugation $(3000 \mathrm{rpm}$ for $2 \mathrm{~min}$ at $4{ }^{\circ} \mathrm{C}$ ). The percentage of zoospores released in the washed zoosporangia suspension was observed under microscope and compared with that of the untreated control.

\subsection{Greenhouse studies}

\subsubsection{Seed treatment and foliar application}

Highly infected seeds (cultivar 7042S) were treated with slurry containing $0.01,0.05,0.1,0.5,1$ or $2 \mathrm{mg}$ $\mathrm{mL}^{-1}$ cyazofamid as a seed dressing, as a seed dressing followed by foliar spray or foliar application alone with cyazofamid at $1,2,3,4,5$ or $10 \mathrm{mg} \mathrm{mL}^{-1}$. Treated seeds were sown in earthen pots containing soil + sand + manure $(2+1+1$ by weight $)$ under greenhouse conditions. Two-day-old seedlings were inoculated with a zoospore suspension of $S$. graminicola $\left(4 \times 10^{4}\right.$ zoospores $\mathrm{mL}^{-1}$ ) following standard protocols. ${ }^{14}$ Cyazofamid foliar spray was applied to inoculated plants (before disease expression) to near run-off on the seventh and fifteenth days after emergence. Distilled water seed treated or foliar-sprayed batches served as controls. Each treatment consisted of 25 plants in four replications. Disease incidence was recorded when the plants were 30 and 60 days old.

\subsection{Fungicide nature}

\subsubsection{Systemic activity of cyazofamid against downy mildew}

The systemic activity of cyazofamid was tested by treating the root regions of ten-day-old downy mildew infected plants raised in pots (25 plants in four replicates per treatment) with suspensions of $1,2,5$ or $10 \mathrm{mg} \mathrm{mL}^{-1}$ cyazofamid. Treatments were made by dipping the roots in the fungicidal suspensions for $30 \mathrm{~min}$. Plants were transplanted to pots and maintained following recommended practices. ${ }^{15}$ Observations were made for recovery from disease 5 days after fungicide root treatments.

\subsubsection{Curative activity}

Twenty-one-day-old downy mildew infected (sporulating) pearl millet plants were sprayed with 1,2 , 
5 or $10 \mathrm{mg} \mathrm{mL} \mathrm{mL}^{-1}$ cyazofamid to near run-off, and plants were then maintained under greenhouse conditions. Each treatment consisted of 25 plants in four replications. Observations were made for inhibition of pathogen as shown by recovery of plants from disease.

\subsubsection{Translaminar activity}

Cyazofamid suspensions of $1,2,5$ or $10 \mathrm{mg} \mathrm{mL}^{-1}$ were applied to ten-day-old downy mildew infected (sporulating) plants either on the abaxial or the adaxial leaf surfaces or on both leaf surfaces by surface smearing. Infected plants smeared with distilled water served as control. Each treatment consisted of 25 plants in four replications. Data on the inhibition of sporulation were recorded in each case after 5 days.

\subsubsection{Residual activity and rainfastness}

Twenty-one-day-old plants were sprayed with suspensions of $1,2,5$ or $10 \mathrm{mg} \mathrm{mL}^{-1}$ cyazofamid. Treated plants were subjected to artificial rain in sleeves by sprinkling with tap water for $2 \mathrm{~h}$, dried overnight and later inoculated with $S$. graminicola $\left(5 \times 10^{4}\right.$ zoospores $\mathrm{mL}^{-1}$ ) and examined for disease symptoms.

\section{RESULTS}

\subsection{Sensitivity of Sclerospora graminicola to cyazofamid}

\subsubsection{Inhibition of sporulation}

A significant $(P<0.001)$ dose-dependent sporulation inhibition was noticed with all the cyazofamid dilutions, $0.01,0.05,0.1,0.15,0.2,0.25$ and $0.3 \mathrm{mg}$ $\mathrm{mL}^{-1}$ (Table 1). With the highest concentration, $0.3 \mathrm{mg}$ cyazofamid $\mathrm{mL}^{-1}, 100 \%$ sporulation inhibition was recorded. Further, a significant inhibition of sporulation to 9750 sporangia $\mathrm{cm}^{-2}$ was found with the low dose of $0.01 \mathrm{mg} \mathrm{mL}^{-1}$, whereas the untreated control recorded 22500 sporangia $\mathrm{cm}^{-2}$.

\subsubsection{Inhibition of zoospore release and motility}

All the tested concentrations proved to be very effective in inhibiting zoospore release and arresting zoospore motility (Table 1). At the lowest concentration of $0.01 \mathrm{mg} \mathrm{mL} \mathrm{mL}^{-1}$, cyazofamid gave 14.2 and $53.2 \%$ inhibition of zoospore release and zoospore motility. Complete inhibition of zoospore release and motility was found at 0.25 and $0.3 \mathrm{mg} \mathrm{mL}^{-1}$ respectively.

\subsubsection{Fungistatic and fungicidal properties of} cyazofamid against Sclerospora graminicola A similar trend in inhibition of zoospore release and arrest of zoospore motility was evident in this trial to that in the sensitivity test (Table 2).

\subsubsection{Seedling emergence}

Seed treatment with different concentrations of cyazofamid revealed significant $(P<0.001)$ enhanced germination to varying degrees (data not shown in the tables). Maximum germination of $93 \%$ was recorded at $1,2,5$ and $10 \mathrm{mg}$ cyazofamid $\mathrm{mL}^{-1}$, whereas in the untreated control only $90 \%$ seed germination was recorded.

\subsubsection{Effect of cyazofamid on downy mildew disease}

None of the concentrations of cyazofamid tested was found to be phytotoxic. No significant disease control was recorded in seed treatments with the lower cyazofamid concentrations (Fig. 1), and only $19.2 \%$ control was obtained at the higher doses of 1 and $2 \mathrm{mg} \mathrm{mL}^{-1}$. However, this was a significant reduction in disease level over the control, which showed $96.2 \%$ disease incidence. Significant disease control was evident when seed treatment with cyazofamid was followed by one foliar spray, 7 days after sowing. Disease control of respectively $73.9,88.4$ and $93.5 \%$ was obtained with foliar sprays of 4,5 and $10 \mathrm{mg} \mathrm{mL}^{-1}$. Moderate disease control (37.4\%) was recorded even at the low concentration of $1 \mathrm{mg} \mathrm{mL}^{-1}$. Highly significant disease control was recorded with a second foliar spray (15 days after sowing), where $99.2 \%$ disease control was recorded at $10 \mathrm{mg} \mathrm{mL}^{-1}$ and $98.2 \%$ at $5 \mathrm{mg} \mathrm{mL}^{-1}$. With foliar spray treatment alone, cyazofamid gave results similar to those with seed treatment plus two foliar sprays at 7 and 15 days after emergence (Fig. 1).

Table 1. In vitro inhibitory effects of cyazofamid on asexual spores of Sclerospora graminicola (host-independent stage) ${ }^{a, b}$

\begin{tabular}{|c|c|c|c|}
\hline Concentration $\left(\mathrm{mg} \mathrm{mL}^{-1}\right.$ ) & $\begin{array}{c}\text { Number of sporangia } \\
\mathrm{cm}^{-2}( \pm \text { SEM })\end{array}$ & $\begin{array}{c}\text { Sporangia releasing } \\
\text { zoospores (\%) ( } \pm \text { SEM) }\end{array}$ & $\begin{array}{l}\text { Zoospores showing } \\
\text { motility (\%) ( } \pm \text { SEM) }\end{array}$ \\
\hline 0.01 & $9750( \pm 478.7) d$ & $14.2( \pm 0.4) d$ & $53.2( \pm 0.6) f$ \\
\hline 0.05 & $9250( \pm 250) d$ & $8.7( \pm 0.2) c$ & $40.7( \pm 0.2) \mathrm{e}$ \\
\hline 0.1 & $5500( \pm 500) \mathrm{c}$ & $8.0( \pm 0) c$ & $34.2( \pm 0.4) d$ \\
\hline 0.15 & $3500( \pm 288.6) b$ & $3.2( \pm 0.6) b$ & $20.5( \pm 0.6) c$ \\
\hline 0.2 & $1500( \pm 288.6) \mathrm{a}$ & $1.2( \pm 0.6) \mathrm{a}$ & $8.5( \pm 0.6) b$ \\
\hline 0.25 & $500( \pm 500) a$ & $0.5( \pm 0.2) \mathrm{a}$ & $0.7( \pm 0.4) \mathrm{a}$ \\
\hline 0.3 & $0 \mathrm{a}$ & $0 \mathrm{a}$ & $0 \mathrm{a}$ \\
\hline Control (distilled water) & $22500( \pm 288.6) \mathrm{e}$ & $91.2( \pm 0.2) \mathrm{e}$ & $100 \mathrm{~g}$ \\
\hline
\end{tabular}

a Values are means of four independent replications.

b Means followed by the same letter(s) within the column are not significantly different according to Tukey's HSD test. 
Table 2. Fungicidal and fungistatic properties of cyazofamid fungicide on asexual spores of Sclerospora graminicola (host-independent stage) ${ }^{a, b}$

\begin{tabular}{lccc}
\hline Concentration $\left(\mathrm{mg} \mathrm{mL}^{-1}\right)$ & $\begin{array}{c}\text { Number of sporangia } \\
\mathrm{cm}^{-2}( \pm \mathrm{SEM})\end{array}$ & $\begin{array}{c}\text { Sporangia releasing } \\
\text { zoospores }(\%)( \pm S E M)\end{array}$ & $\begin{array}{r}\text { Zoospores showing } \\
\text { motility }(\%)( \pm S E M)\end{array}$ \\
\hline 0.01 & $3000( \pm 408.2) \mathrm{c}$ & $13( \pm 0.7) \mathrm{c}$ & $48.5( \pm 0.5) \mathrm{f}$ \\
0.05 & $1750( \pm 250) \mathrm{bc}$ & $12.5( \pm 0.4) \mathrm{c}$ & $37.2( \pm 0.6) \mathrm{e}$ \\
0.1 & $1000( \pm 408.2) \mathrm{ab}$ & $11( \pm 0.4) \mathrm{c}$ & $24.2( \pm 0.4) \mathrm{d}$ \\
0.15 & $1000( \pm 0) \mathrm{ab}$ & $5.2( \pm 0.4) \mathrm{b}$ & $11.2( \pm 0.2) \mathrm{c}$ \\
0.2 & $500( \pm 288.6) \mathrm{ab}$ & $1.7( \pm 0.4) \mathrm{a}$ & $4.2( \pm 0.2) \mathrm{b}$ \\
0.25 & $250( \pm 250) \mathrm{a}$ & $0 \mathrm{a}$ & $0.2( \pm 0.2) \mathrm{a}$ \\
0.3 & $0 \mathrm{a}$ & $91( \pm 0.4) \mathrm{d}$ & $0 \mathrm{a}$ \\
Control (distilled water) & $22250( \pm 250) \mathrm{d}$ & $100 \mathrm{f}$ \\
\hline
\end{tabular}

a Values are means of four independent replications.

b Means followed by the same letter(s) within the column are not significantly different according to Tukey's HSD test.

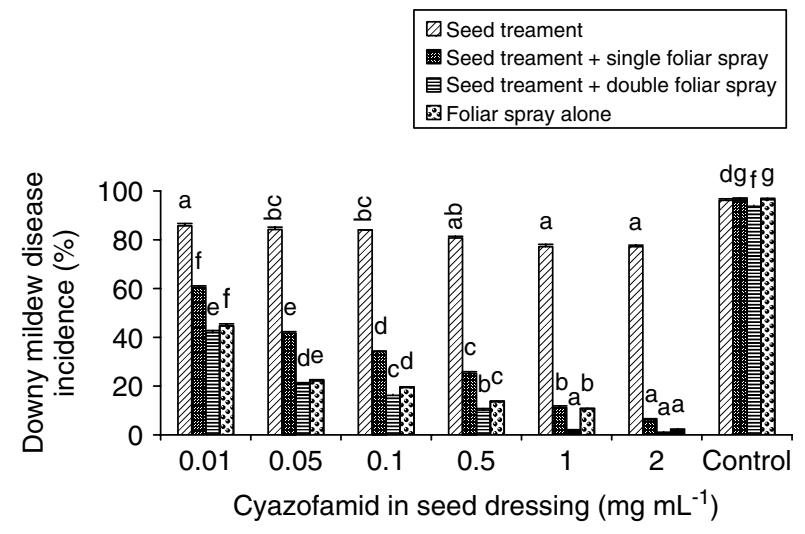

Figure 1. Efficacy of cyazofamid against downy mildew disease of pearl millet under greenhouse conditions. Values are means of four independent replications. Bars represent standard errors. Means followed by the same letter(s) within the column are not significantly different according to Tukey's HSD test.

\subsection{Fungicide nature}

\subsubsection{Systemic activity of cyazofamid against downy mildew}

Root treatment of infected seedlings with cyazofamid left them susceptible, with a disease incidence of 87.7, 89.2 and $89.7 \%$ with 10,5 and $2 \mathrm{mg}$ cyazofamid $\mathrm{mL}^{-1}$ respectively (Fig. 2). This clearly indicates that the fungicide does not have systemic action against downy mildew disease in pearl millet. Although major systemic action was not observed from root treatments, slight disease control was noticed in the treatments, and the disease level was significantly different from that in the control.

\subsubsection{Curative activity}

When sprayed with $1,2,5$ or $10 \mathrm{mg}$ cyazofamid $\mathrm{mL}^{-1}$ to run-off, 21-day-old downy mildew infected pearl millet plants showed varied levels of recovery from disease (Fig. 3), with respectively 35.3, 42.3, 74 and $91 \%$ cure.

\subsubsection{Translaminar activity}

Cyazofamid applied to the abaxial regions showed a disease incidence of $63,41.5,24.7$ and $16 \%$ in treatments with $1,2,5$ and $10 \mathrm{mg} \mathrm{mL}^{-1}$ respectively (Fig. 4). However, movement of fungicide from

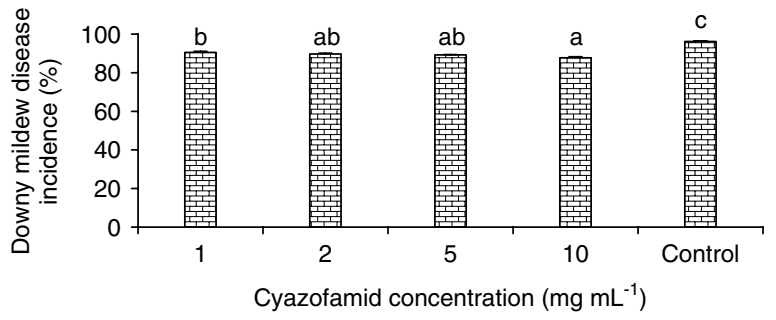

Figure 2. Systemic activity of cyazofamid by root treatment of downy mildew infected pearl millet seedlings, as demonstrated by inhibition of disease. Values are means of four independent replications. Bars represent standard error. Means followed by the same letter(s) within the column are not significantly different according to Tukey's HSD test.

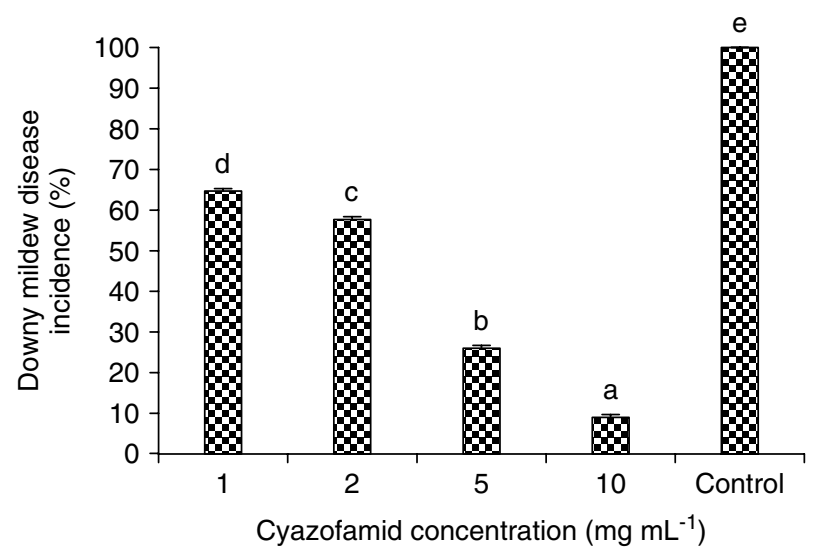

Figure 3. Curative activity of cyazofamid sprayed on 21-day-old highly infected plants. Values are means of four independent replications. Bars represent standard error. Means followed by the same letter(s) within the column are not significantly different according to Tukey's HSD.

adaxial surfaces was very poor, as evidenced by retention of higher disease percentages of 96, 88.2, 79.7 and $65.2 \%$ on the abaxial surfaces at $1,2,5$ and $10 \mathrm{mg} \mathrm{mL}^{-1}$ respectively. Cyazofamid applied to both surfaces significantly inhibited the development of disease, with $44,28,7.7$ and $2.7 \%$ incidence at 1 , 2,5 and $10 \mathrm{mg} \mathrm{mL}^{-1}$ respectively.

\subsubsection{Residual activity and rainfastness}

In the residual activity and rainfastness tests, significant disease control was evident with all cyazofamid 


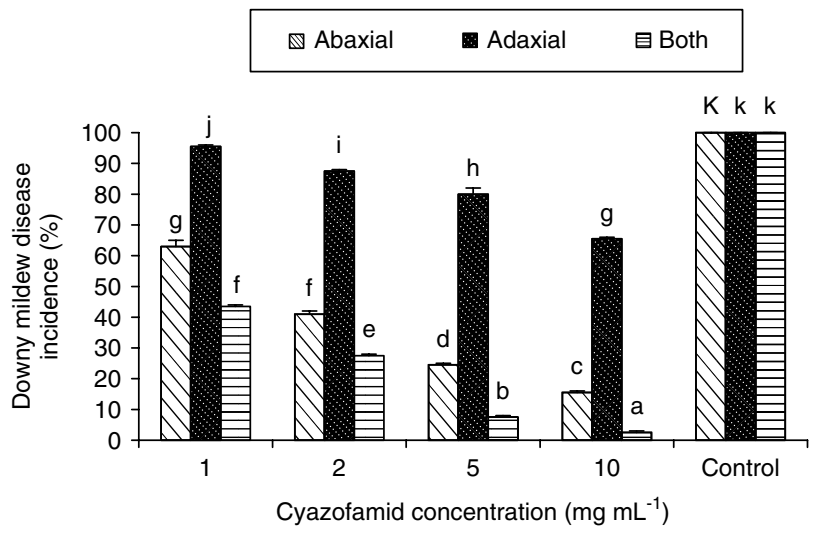

Figure 4. Translaminar activity of cyazofamid in infected pearl millet leaves, as indicated by inhibition of downy mildew disease. Values are means of four independent replications. Bars represent standard error. Means followed by the same letter(s) within the column are not significantly different according to Tukey's HSD test.

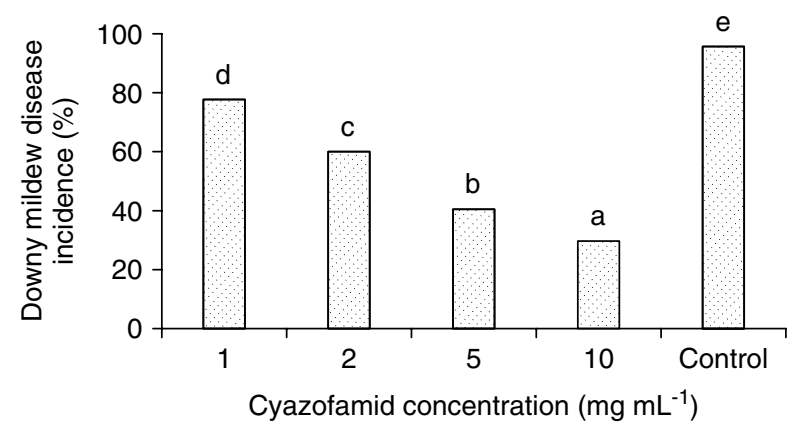

Figure 5. Residual activity and rainfastness of cyazofamid. Values are means of four independent replications. Bars represent standard error. Means followed by the same letter(s) within the column are not significantly different according to Tukey's HSD test.

concentrations tested (Fig. 5). Among the tested concentrations, $10 \mathrm{mg} \mathrm{mL}^{-1}$ provided maximum disease control of $71 \%$, followed by $5 \mathrm{mg} \mathrm{mL}^{-1}(57.6 \%$ disease control), and the lowest dose, $1 \mathrm{mg} \mathrm{mL}^{-1}$, also gave partial disease control of $18.8 \%$ compared with the untreated control. This result clearly indicates that loss of cyazofamid activity was relatively small.

\section{DISCUSSION}

Cyazofamid exhibited strong inhibition of zoospore motility and zoospore release of $S$. graminicola in vitro (Table 1). Inhibition of zoospore motility was significantly superior to that of zoospore release at the same concentration. These observations are consistent with those from experiments with Phytophthora infestans (Mont.) De Bary. ${ }^{7}$ Cyazofamid strongly inhibited all stages in the life cycle of $P$. infestans, including zoospore release, zoospore motility, cystospore germination and oospore formation and mycelial growth. Among these, cyazofamid was most active against zoospore motility in terms of the concentration required for $50 \%$ inhibition.

Zoosporangia viability was evaluated by zoospore release and zoospore motility of $S$. graminicola. When zoosporangia were separated from cyazofamid after 15 min incubation, inhibition of zoospore release and zoospore motility was observed (Tables 1 and 2). This activity was comparable with that found after more than $60 \mathrm{~min}$ incubation with cyazofamid, indicating rapid fungicidal action, and that treatment for more than $15 \mathrm{~min}$ had no further effect. Similar effects were observed on sporulation activity in vivo (Tables 1 and 2). There are two previous reports concerning the action of cyazofamid on the viability of fungi for the control of plant diseases. In a viability test using zoosporangia of $P$. infestans, cyazofamid at $0.1 \mu \mathrm{g} \mathrm{mL}^{-1}$ exhibited irreversible inhibition of zoospores after $60 \mathrm{~min}$ incubation. ${ }^{7}$ Another example is that cyazofamid at $3-10 \mu \mathrm{g} \mathrm{mL}^{-1}$ showed fungicidal activity against resting spores of Plasmodiophora brassicae Woron 1-10 days after treatment, leading to a reduction in root hair infection on Chinese cabbage. ${ }^{10}$

Cyazofamid exhibited strong preventive, residual, curative and sporulation inhibition activity, and rainfastness against $S$. graminicola under greenhouse conditions (Figs. 3 and 5). The fungicide had only limited translaminar activity (Fig. 4). These observations are consistent with those from experiments against $P$. infestans and Pseudoperonospora cubensis (Burk. \& Curt.) Rostov., except for curative activity. ${ }^{11}$ Cyazofamid exhibited no curative activity against $P$. infestans and moderate activity against $P$. cubensis in pot tests. However, in some field trials, this fungicide exhibited curative activity against both $P$. infestans on potato and $P$. cubensis on cucumber. ${ }^{1-13}$ Since cyazofamid had high levels of curative activity against $S$. graminicola on pearl millet in a pot test (Fig. 3), this fungicide would exhibit curative activity against the disease in the field.

Seed treatment with cyazofamid at all concentrations tested, $1,2,5$ and $10 \mathrm{mg} \mathrm{mL}^{-1}$, enhanced pearl millet germination. This result suggests that cyazofamid may contribute to suppressing microorganism epidemics on the seed surface that affect pearl millet germination. Another possibility is that this phenomenon arises from an unknown mechanism of cyazofamid.

Downy mildew caused by $S$. graminicola is one of the most damaging diseases of pearl millet. ${ }^{3}$ Three fungicide applications are traditionally recommended in India, before sowing (seed treatment) and at the seventh and fourteenth day after emergence. Tests of seed treatment using artificial inoculation with cyazofamid did not provide any significant disease control. On the other hand, seed treatment plus foliar application gave protective activity, with 4,5 and $10 \mathrm{mg}$ $\mathrm{mL}^{-1}$ clearly suppressing the development of downy mildew disease. It is emphasized that foliar treatment alone was effective and gave similar reaction to that with seed treatment plus foliar application (Fig. 1). This indicates that cyazofamid should be used as a foliar application. Since it is extremely unlikely that cyazofamid alone will be used for an entire season 
on the basis of resistant management strategy, ${ }^{16}$ alternative applications with other fungicides that have different modes of action should be used. We have previously reported the efficacy of the strobilurin fungicides, azoxystrobin, trifloxystrobin and kresoximmethyl, against pearl millet downy mildew at low concentrations. ${ }^{15}$ In the present study, cyazofamid exhibited a similar trend against $S$. graminicola inhibition and disease control using higher concentrations under both in vitro and in vivo conditions. Strobilurins have different biological properties that consequently confer a wide range of biokinetic behaviour. All the commercialized strobilurins can be demonstrated to have broad-spectrum activity with non-selective toxicity against the target enzyme.

Cyazofamid has strong preventive activity, residual activity, rainfastness and sporulation inhibitory activity. Translaminar and curative activity are moderate (curative activity against pearl millet downy mildew is strong). Cyazofamid strongly inhibits the target enzyme only of Oomycetes. All fungicides can be used for seed treatment as well as foliar application. The carboxylic acid amide (CAA) fungicide iprovalicarb also had potential for the control of downy mildew of pearl millet, ${ }^{17}$ and this and related fungicides can be included in control programmes.

Cyazofamid belongs to a new class of fungicide with a mode of action that is different from that of the strobilurins and iprovalicarb. Mode of action studies have shown that strobilurins act against mitochondrial cytochrome $b c_{1}$ at the $\mathrm{Q}_{0}$ site $^{18,19}$ and iprovalicarb does not affect respiration. ${ }^{20}$ Although the mode of action of iprovalicarb and other CAA compounds has not yet been fully elucidated, there are proposals that they inhibit phospholipid biosynthesis and interfere with cellwall deposition (http://www.frac.info/frac/index.htm). Further investigations are needed to establish the most efficient sequential treatments to include cyazofamid against pearl millet downy mildew.

In conclusion, cyazofamid has a high potential to be an effective fungicide for the control of pearl millet downy mildew. This is the first report that cyazofamid exhibits high activity against $S$. graminicola and is a promising fungicide in controlling this disease by foliar treatment.

\section{ACKNOWLEDGEMENTS}

The authors thank the Indian Council of Agricultural Research (ICAR), Government of India, through the All-India Coordinated Pearl Millet Improvement Programme (AICPMIP), for laboratory and field facilities, and the Central Research Institute, Ishihara Sangyo Kaisha Ltd, Shiga, Japan.

\section{REFERENCES}

1 Bhatnagar SK, Kharwal IS and Pareek S, Pearl millet nucleus and breeder seed production. Technical Bulletin, All-India Coordinated Pearl Millet Improvement Programme (AICPMIP), Jodhpur, India (2002).

2 Shetty SA, Shetty HS and Mathur SB, Downy mildew of pearl millet, Technical Bulletin, Downy Mildew Research Laboratory, Department of Studies in Applied Botany, University of Mysore, Manasagangotri, Mysore, India (1995).

3 Singh SD, Downy mildew of pearl millet. Plant Dis 60:545-550 (1995).

4 Thakur RP and Mathur K, Downy mildews of India. Crop Prot 21:333-345 (2002).

5 Exconde OR and Monila AB, Ridomil (Ciba Geigy) a seed dressing fungicide for the control of Phillippine corn mildew. Phillip F Crop Sci 3:60-64 (1978).

6 Singh SD and Shetty HS, Efficacy of systemic fungicide metalaxyl for the control of downy mildew (Sclerospora graminicola) of pearl millet (Pennisetum glaucum). Ind $\mathcal{F}$ Agric Sci 60:575-581 (1990).

7 Mitani S, Araki S, Yamaguchi T, Takii Y, Ohshima T and Matsuo N, Antifungal activity of the novel fungicide cyazofamid against Phytophtora infestans and other plant pathogenic fungi in vitro. Pestic Biochem Physiol 70:92-99 (2001).

8 Mitani S, Araki S, Takii Y, Ohisma T, Matsuo N and Miyoshi H, The biochemical mode of action of the novel selective fungicide cyazofamid: specific inhibition of mitochondrial complex III in Pythium spinosum. Pestic Biochem Physiol 71:107-115 (2001).

9 Mitani S, Araki S, Matsuo N and Camblin P, Proc Brighton Crop Prot Conf-Pests and Diseases, BCPC, Farnham, Surrey, UK, pp. 351-358 (1998).

10 Mitani S, Sugimoto K, Hayashi H, Takii Y, Ohshima T and Matsuo N, Effects of cyazofamid against Plasmodiophora brassicae Woronin on Chinese cabbage. Pest Manag Sci 59:287-293 (2003).

11 Mitani S, Araki S, Yamaguchi T, Takii Y, Ohshima T and Matsuo N, Biological properties of the novel fungicide cyazofamid against Phytopthora infestans on tomato and Pseudoperonospora cubensis on cucumber. Pest Manag Sci 58:139-145 (2001).

12 Mitani S, Kamachi K, Sugimoto K, Araki S and Yamaguchi T, Control of cucumber downy mildew by cyazofamid. $\mathcal{F}$ Pestic Sci 28:64-68 (2003).

13 Mitani S, Kamachi K and Sugimoto K, Control of potato late blight by cyazofamid. F Pestic Sci 30:116-119 (2005).

14 Singh SD and Gopinath R, A seedling inoculation technique for detecting downy mildew resistance in pearl millet. Plant Dis 69:425-428 (1985).

15 Sudisha J, Amruthesh KN, Deepak SA, Shetty NP, Sarosh BR and Shetty HS, Comparative efficacy of strobilurin fungicides against downy mildew disease of pearl millet. Pestic Biochem Physiol 81:188-197 (2005).

16 Brent JB, Fungicide resistance in crop pathogens. How can it be managed? FRAC Monograph No. 1, GIFAP, Bristol, UK, 48 pp. (1995).

17 Deepak SA, Oros G, Niranjan Raj S, Shetty NP and Shetty HS, Iprovalicarb has potential for the control of downy mildew of pearl millet. Acta Phytopathol Entomol Hungaria 39:55-69 (2004).

18 Wiggins TE and Jager BJ, Mode of action of the new methoxyacrylate antifungal agent ICIA5504. Biochem Soc Trans 22:68S (1993).

19 Bartlett DW, Clough JM, Godwin JR, Hall AA, Hamer M and Parr-Dobrzanski B, The strobilurin fungicides. Pest Manag Sci 58:649-662 (2002).

20 Stenzel K, Pontzen R, Seitz T, Tiemann R and Witzenberger A, SZX 722: a novel systemic oomycete fungicide. Proc Brighton Crop Prot Conf - Pests and Diseases, BCPC, Farnham, Surrey, UK, pp. 361-374 (1998) 